\title{
Quantifying the influence of environmental and water conservation attitudes on household end use water consumption
}

\section{Authors:}

\section{Rachelle M. Willis}

Ph.D. Candidate, School of Engineering, Griffith University, Gold Coast Campus 4222, Australia, Email: r.willis@griffith.edu.au

\section{Rodney A. Stewart (corresponding author)}

Director, Centre for Infrastructure Engineering \& Management, Griffith University, Gold Coast Campus 4222, Australia, Email: r.stewart@griffith.edu.au

\section{Kriengsak Panuwatwanich}

Lecturer, School of Engineering, Griffith University, Gold Coast Campus 4222, Australia, Email: k.panuwatwanich@griffith.edu.au

\section{Philip R. Williams}

Senior Lecturer, School of Engineering, Griffith University, Gold Coast Campus 4222, Australia, Email: p.williams@griffith.edu.au

\section{Anna L. Hollingsworth}

Senior Infrastructure Planning Officer, Allconnex Water, PO Box 5042, Gold Coast Mail Centre, Queensland 9729, Australia, Email: anna.hollingsworth@allconnex.com.au

\section{Citation:}

Willis, R.M., Stewart, R.A., Panuwatwanich, K., Williams, P.R., Hollingsworth, A.L., 2011b. Quantifying the influence of environmental and water conservation attitudes on household end use water consumption. Journal of Environmental Management, 92, pp. 1996-2009, doi:10.1016/j.jenvman.2011.03.023

Contact: r.stewart@griffith.edu.au 


\title{
Quantifying the influence of environmental and water conservation attitudes on household end use water consumption
}

\begin{abstract}
Within the research field of urban water demand management, understanding the link between environmental and water conservation attitudes and observed end use water consumption has been limited. Through a mixed method research design incorporating field-based smart metering technology and questionnaire surveys, this paper reveals the relationship between environmental and water conservation attitudes and a domestic water end use break down for 132 detached households located in the Gold Coast, Australia. Using confirmatory factor analysis, attitudinal factors were developed and refined; households were then categorised based on these factors through cluster analysis technique. Results indicated that residents with very positive environmental and water conservation attitudes consumed significantly less water in total and across the behaviourally influenced end uses of shower, clothes washer, irrigation and tap, than those with moderately positive attitudinal concern (n=78; 169.0L/p/d). The paper concluded with implications for urban water demand management planning, policy and practice.
\end{abstract}

Key words: smart metering; environmental attitudes; water conservation attitudes; domestic water end use, water demand management 


\section{Introduction}

An escalating demand on potable water resources resulting from increasing populations, droughts and unpredictable weather patterns due to climate change is commonplace in many parts of the world (Bates et al., 2008; Commonwealth of Australia, 2008b). As a result, the sustainable management of urban water has become imperative, particularly for countries prone to severe droughts such as Australia. Australia receives the lowest average annual rainfall of all inhabited continents and is experiencing strong population growth in urban areas (Birrell et al., 2005; Commonwealth of Australia, 2008a). In response a range of sustainable water management practices and principles have been introduced to ensure the secure supply of urban water. Notably, water demand management (WDM) initiatives are utilised to assist in shifting consumers towards sustainable water consumption behaviour. WDM is defined as the practical 'development and implementation of strategies aimed at influencing demand' (Savenije and van der Zaag, 2002, pp. 98). It is characterised by reducing average water consumption to ensure efficient and sustainable use of the resource (Tate, 1993; Deverill, 2001; Brooks, 2002; 2006). WDM measures are generally the most sustainable solutions across environmental, social and economic factors, in the range of options presented for water supply security (White et al., 2007). WDM measures focus on reducing end use consumption hence offsetting the need for additional water supply and wastewater treatment measures which are costly and can be environmentally and socially detrimental. Initiatives for WDM are focused on supplying tools, mechanisms and knowledge to enable residents to continually reduce their potable water consumption (through the reduced use of water-using devices or uptake of water-efficient devices). The WDM approach relies heavily on consumers to understand how to reduce their water consumption and to apply this understanding to everyday activities to consume sustainably. 
Past research has determined that water consumption within households is dependent on numerous factors, which include: the number of people in the house, the age of residents, education levels of residents, lot size of properties, residents' income, efficiency of water consuming devices (i.e. clothes washers, shower heads, tap fittings, dishwashers and toilets) and the attitudes, beliefs and behaviours of consumers (Nieswaidomy and Molina, 1989; Renwick and Archibald, 1998; Mayer and DeOreo, 1999; Renwick and Green, 2000; Inman and Jeffrey, 2006).

The pricing of water was initially predicted to influence consumption but this belief has more recently been dispelled, with research demonstrating that in most cases residential water demand is largely price inelastic because of its low relative cost when compared to other life essentials (Worthington and Hoffmann, 2008; Barrett 2004). Barrett's (2004) investigation of 30 residential water price demand studies revealed that most indicated price inelasticity, with evidence that only very large external users being more likely to be sensitive to price changes. Earlier end use studies have demonstrated that households with very high incomes consume more water externally while, the variation of internal water consumption remains similar and is not statistically significant between income levels (Mayer and DeOreo, 1999; Loh and Coghlan, 2003). External consumption is the end use detailed to be most effected by income and the cost of water (Mayer and DeOreo, 1999). Mayer and DeOreo (1999) have reported a positive relationship between larger lot sizes and higher outdoor water consumption in the USA while, Loh and Coghlan (2003) found that this was not the case in Australia. In fact there was no evidence of a relationship between irrigable area and external household usage present (Loh and Coghlan, 2003). Elements which were found to increase external water use in both studies were the ownership of automated irrigation systems and swimming pools (Mayer and DeOreo, 1999; Loh and Coghlan, 2003). 
In relation to WDM, the last group of factors (i.e. attitudes, beliefs and actual behaviours of consumers) are particularly relevant as water management initiatives often include pressure on residents to reduce household water consumption through undertaking more sustainable water consumption practices. Shifting residents toward sustainable water consumption practices thus requires the instilling of awareness, understanding and appreciation of the environment and water. Establishing a connection between attitudes and beliefs concerning water and the environment and their relationship on actual water consumption behaviour has been undertaken previously (Nancarrow et al., 1996; Hassell and Cary, 2007). However, empirical studies that quantify the nature of such a relationship are still largely lacking within the current body of knowledge. To fill this gap, the herein described research was aimed to empirically investigate how attitudes and beliefs influence urban end use water consumption behaviour.

The objectives of this research include:

- Developing measurable research propositions relating to attitudes and domestic end use water consumption behaviour;

- Undertaking a field-based smart metering study and subsequent flow trace analysis process to disaggregate domestic water end uses for a statistically significant sample;

- Exploration of the characteristics of consumers with respect to their attitudes towards the environment and water conservation;

- Investigation on the relationship between a confirmed taxonomy of attitudinal constructs and end use water consumption; and,

- Confirming the environmental and water conservation attitudes of residential households that significantly affect behaviourally influenced (i.e. life style choice such as longer than required showers) end use water consumption levels. 
Meeting these objectives will enable water professionals to effectively target WDM education and awareness programs, thus yielding higher water savings for such initiatives. Ultimately, research outcomes could be subsequently integrated into national water planning and management strategies to enhance long term WDM practices. The paper presents the theoretical background relevant to understanding the attitudes and behaviours that affect domestic water consumption and conservation. Following this is a description of research propositions. The adopted research method is detailed along with data analysis and results. Key findings are discussed with the paper concluding by deliberating on managerial implications.

\section{Theoretical background}

\subsection{Water consumption attitudes and behaviour}

Determining motives for saving water are key when designing educational urban water saving strategies; hence at the outset, an understanding of consumption and attitudes towards water is vital (Corral-Verdugo et al., 2003). It has been previously established that the attitudes and beliefs of consumers directly impact on water use behaviours which are closely linked to water demand (Hassell and Cary, 2007). To understand the embodiment of people's attitudes and behaviour, and their association with water consumption, Ajzen and Fishbein's (1980) theory of reasoned action was adopted as a point of departure.

Ajzen and Fishbein's theory conceptualises the linkages between beliefs, attitudes, perceived social norms and behaviours by building on the expectancy value theory through the incorporation of normative social influence on behavioural intention (Hassell and Cary, 2007). This theory was employed to assist in the establishment of a baseline model to undertake attitudinal analysis. Several earlier research studies adopted the same approach to investigate attitudes and their impact on water consumption behaviour. For example, Syme 
and Nancarrow (1992) and Po et al. (2005) have applied Ajzen and Fishbeins' theory of reasoned action to explain the extent to which intended behaviour could predict actual consumer responses to water supply systems. When considering risks and other social elements, the model was particularly useful for predicting behaviour associated with the delivery of potable water (Hassell and Cary, 2007).

To better understand and capture the above attitudinal concept, two main factors were identified as having an influence on water consumption from a review of earlier research, being: (1) Concern for Environment (CE); and (2) Water Conservation Awareness and Practice (WC). Following Nancarrow et al. (1996), these two primary attitudinal factors can be used to assess the 'way in which people think about water'. Past research on the effect of such attitudinal factors on water consumption is examined in the following sections.

\subsubsection{Concern for environment}

The link between general environmental beliefs and conservation behaviour has been detailed by DECC (2007), Kordiatis et al. (2004) and Corral-Verdugo et al. (2003). Surveys undertaken by Kordiatis et al. (2004) determined that attitudes towards environmental issues were in fact reliable predictors of environmental behaviour. Corral-Verdugo et al. (2003), drawing on the instrument commonly used to measure general environmental beliefs, namely, the New Environment Paradigm-Human Exception Paradigm (NEP-HEP), exclusively investigated the relationship between general environmental beliefs and water conservation behaviour. In Sonora, Mexico, surveys were undertaken to establish environmental beliefs in general as well as environmental beliefs specific to the connection of water as a natural resource, along with demographic details with water consumption recorded and estimated through a diary approach (Corral-Verdugo et al., 2003). The results supported the hypothesis that general environmental beliefs significantly influence domestic water consumption 
behaviour when beliefs and behaviours are assessed at a corresponding level of specificity (Corral-Verdugo et al., 2003).

More recently, Gilg and Barr (2006) carried out a study of 1,265 households in Devon, UK exploring the relationship between environmental attitudes and behaviours focussing on total urban water use as the primary interest. The research examined if there were substantive links between environmental actions and water saving behaviour to determine behavioural variations associated with environmental activist classification (Gilg and Barr, 2006). Results indicated that committed environmentalists and main stream environmentalists were most likely to engage in energy and water saving activities regularly. Recent longitudinal research by DECC (2007), assessing public attitudes to the environment including water related issues across Australia, has determined a growing concern for environmental and water issues with respondents identifying a willingness to undertake sustainable actions or behaviours.

The review of prior research assisted in establishing a derived factor representing environmental concern consisting of eight indicators being: protection of natural environment for future generations; community responsibility for reducing water consumption; concern for environmental problems; joint responsibility of government and community to ensure water security; acknowledgement of water being a valuable resource; acknowledgement of one’s role in creating a sustainable water future; valuing recycling, composting and other environmentally sustainable activities; and acknowledgement of humans role as caretaker for environment. Details of these indicators along with their associated references are presented in Table 1. These listed elements are refined and confirmed in the latter part of the paper to ensure they are appropriate measurable indicators of the derived environmental concern factor.

[Insert Table 1] 


\subsubsection{Water conservation awareness and practice}

Water conservation awareness and practice involves understanding the efficiency, opportunities and impacts of certain water saving activities as well as the desire to continually reduce consumption (Nancarrow and Syme, 1989; CSIRO, 2002; Gilg and Barr, 2006; Heinrich, 2007). Water conservation relating to concern for water as a scarce resource was investigated in a major study by Nancarrow et al. (1996), who determined from the investigation that the ways people think about water does not predict their water consumption, contradicting the findings from other studies in the field (Middlestadt et al., 2001; CSIRO, 2002). Nancarrow and colleagues reasoned that this outcome may be due to the adopted method of recording water consumption data at a household level through a diary approach, while survey data was collected as individual responses.

Middlestadt et al. (2001) similarly explored the relationship of knowing or having the knowledge on how to conserve water and whether this translated into actual behaviour. The research determined that students who were taught and understood water conservative behaviours more regularly performed these behaviours. The CSIRO (2002) carried out an extensive study in Perth, utilising both diary and end use monitoring methods, to determine attitudes of consumers and water consumption with investigations indicating that attitudinal variables affect external or outdoor water consumption (CSIRO, 2002). Unfortunately, the link between attitudinal factors and indoor end use water consumption was not reported on. Hence, this study set out to examine the influence of attitudes on indoor and outdoor domestic water end use.

Through an extensive review of literature, nine indicators were uncovered that serve to represent the derived water conservation awareness and practice factor, being: awareness of opportunities to save water in household; awareness of the water saving benefits of retrofitting to water efficient fixtures and appliances; water meter reading competency; 
monitoring of water use; awareness of the relationship between behaviour and water consumption; water saving know-how; perception on efficiency of household water use practices/behaviours; seeking continuous savings in water consumption over the longer term; and regular water meter reading. These items are described succinctly in Table 2, and are assessed in the latter part of the paper to ensure they are appropriate measurable indicators of the derived water conservation and practice factor. Once confirmed, this, along with the environmental concern factor were subsequently utilised to determine the effect of attitudes on domestic end use water consumption.

[Insert Table 2]

\subsection{Water end use monitoring}

Effective water monitoring techniques are essential for understanding domestic water consumption behaviour (Stewart et al., 2010). Many water authorities provide information on how to read a water meter to consumers with the belief that knowledge of water consumption will assist in conserving water. Determination of water consumption within a household, however, requires specific knowledge on how, where, when and who consumes water within them. Initially, determining such elements of consumption relied on the honesty and vigilance of residents through diary recording methods. Water consumption studies utilised a diary recording method to establish end water usage. The diary method involves a member of the household noting down every water consuming event i.e. a shower, toilet flush or tap use. The nominated recorder would also note who carried out the event and the event duration (CSIRO, 2002; Cordell et al., 2003). Issues such as the subjectivity of measurements, consistency of people to record all information and the influence on behaviour through recording methods led to the development of a less intrusive and more accurate measurement method in the form 
of smart metering (Cordell et al., 2003). The development of smart metering technology has eliminated the error of the older end use recording methods being, diary records, resulting in accurate records of end use water consumption within residential households.

The advent of smart water metering enabled water consumption to be monitored at an end use level, resulting in the identification of individual water use events, such as shower, toilet flushing, tap use or irrigation, through the use of appropriate software (Willis et al., 2009; Willis et al., 2011). Smart metering involves the application of a high resolution water meter and a data logger to obtain a continuous record of accurate water consumption data. This smart metering approach has been utilised in many water end use studies conducted worldwide. Details of the results of the more significant end use studies conducted throughout the world are presented in Table 3.

[Insert Table 3]

Table 3 shows that in the Australia-Pacific region, the highest residential end uses are showers, clothes washing, irrigation, toilet and tap use (Loh and Coghlan, 2003; Roberts, 2005; Heinrich, 2007). These earlier studies established end use water consumption in their respective regions and undertook analysis exploring the differences in end use consumption due to the influence of socio-demographic variables. These studies, however, did not demonstrate or provide any statistical indication of the influence of the abovementioned attitudinal factors on various types of end use water consumption.

Understanding water consumption at the end use level is critical due to the fact that overall domestic water consumption is made up of different water end use events. Broadly, water use can be categorised into two main areas: non-discretionary and discretionary end uses (ACTCOSS and CCSERAC, 2003). Traditionally, non-discretionary water use is defined as the water used within the house to meet daily consumption and sanitation needs (e.g. 
shower, clothes washing); whereas discretionary end uses are additional non-essential water use activities (e.g. irrigation, pool use). However, lifestyle changes towards over consumption have shifted many essential water end uses to include a large discretionary component, where use can be well beyond what is required or considered publically acceptable for the activity. For example, showering is now often utilised as a leisure or relaxation activity rather than simply being used for sanitation needs. This behavioural shift epitomises the 'Human Exception Paradigm', a belief that humans are above nature and therefore do not have to regard the environment when they consume resources (Bechtel et al., 1999). Therefore, this research argues that discretionary water end uses should refer to those end use events that are likely to be dependent and influenced by the lifestyle and behaviour of an individual. While certain volumes of use are required for basic sanitation needs in shower, clothes washing and tap end uses, usage above and beyond a reasonable sanitation requirement is argued to be discretionary. The World Health Organization (WHO) stipulates that basic long term sustainable water consumption for emergencies requires between 40 to 70 litres per person per day $(\mathrm{L} / \mathrm{p} / \mathrm{d})$ for personal drinking, sanitation and additional activities such as house cleaning, growing food and waste disposal (WHO, 2005). A detailed investigation into basic water requirements to meet human needs by Gleick (1996) also determined that $50 \mathrm{~L} / \mathrm{p} / \mathrm{d}$ of clean water is a fundamental human right. While everyday living and consumption in a developed country cannot be based on WHO guidelines, these figures emphasise that modern households in developed nations consume far more than what is reasonably required for basic sanitation and consumption needs. Based on the core end use categories mentioned above, irrigation, shower, tap, and clothes washing could be considered uses that have a significant discretionary component, and toilet non-discretionary when considering this refined definition of discretionary end uses (i.e. toilets are a fixed consumption end use with limited behavioural 
influence). Leakage is not considered discretionary or non-discretionary as this use is not a basic need nor is it influenced by behaviour.

\subsection{Research propositions}

It is evident from the preceding sections that several investigations have established the importance of environmental and water conservation attitudes on consumption behaviour. Most demonstrate that positive attitudes and commitment towards the environment and water conservation result in undertaking sustainable water conservation behaviours which, in turn, results in lower water consumption. Hence, the following research proposition was developed:

Proposition 1: Households with higher levels of environmental concern and positive attitudes towards water conservation will have significantly lower levels of total water consumption.

In addition, since smart metering techniques allow for the accurate recording of water consumption in specific end use categories, the relationships between behavioural attitudes and various household end uses was further examined. Theoretically, because certain water consumption end uses tended to be highly influenced by attitudes and behaviour, additional propositions were formulated to provide specific understanding on the impact of attitudinal factors on end use water consumption behaviour:

Proposition 2a: Households with higher levels of environmental concern and positive attitudes towards water conservation will have significantly lower levels of water consumption across behaviourally influenced end uses (i.e. there is a significant discretionary component to particular water end use such as showering, irrigation, etc.). 
Proposition $2 b$ : There is no significant difference in the consumption of water end uses which have a lower behavioural influence (e.g. toilet flushing), between households that have different levels of environmental concern and attitude towards water conservation. These end uses generally have a fixed and/or low water consumption volume per event.

The following section presents the research method undertaken to test the above detailed research propositions.

\section{Research method}

The research forms a component of the Gold Coast Watersaver End Use (GCWSEU) study. This element of the study integrates and compares end use water consumption data and attitudinal questionnaire survey data to obtain an understanding of the influence of attitudes on actual water end use consumption. Two concurrent research activities were carried out being: (1) water end use data collection and analysis, utilising smart metering technologies and flow trace analysis software for event disaggregation, respectively; and (2) the development, application and statistical analysis of an attitudinal and demographic questionnaire survey.

\subsection{Situational context}

Water security is of critical concern in the urbanised South East Queensland (SEQ) region of Australia. SEQ includes the populations in and between Brisbane, the Gold Coast, Sunshine Coast and Toowoomba, with the total current population of above 2.8 million people. In the Gold Coast (population half a million people), residential water consumption accounts for approximately 75\% of the City's total supply (2008/2009) compared with 57\% in nearby 
Brisbane City (population 1.8 million people). These high residential water consumption percentages triggered a focus on residential water users to continually reduce consumption. Relative to the SEQ water supply situation, the water restriction level and awareness messages on water are constantly changing hence it is important to set the context during the data collection period. Leading up to the data collection period, the Gold Coast had been on Level 6 water restrictions which dictate a total outdoor watering ban and encourage residents to consume $140 \mathrm{~L} / \mathrm{p} / \mathrm{d}$. Drought breaking rainfalls then occurred, which led to all water restriction levels being lifted before the data collection period. This relaxation of restrictions was due to the Hinze Dam, the Gold Coast's primary water source, being at greater than 95\% capacity. Leading up to and during the data collection period, frequent messages on saving water in the home, using $140 \mathrm{~L} / \mathrm{p} / \mathrm{d}$ and rebates programs for installing water efficient devices such as the 'Home Watersaver' were in place. End use data was collected from the sampled single detached households in July 2008. There were no water restrictions in place during the data collection period. The month of July saw $129.8 \mathrm{~mm}$ of rain fall, with ten rainfall days above $1 \mathrm{~mm}$ recorded. Bulk supplied single detached residential consumption in the Gold Coast for July was $161.9 \mathrm{~L} / \mathrm{p} / \mathrm{d}$.

\subsection{Research sample}

Data collection was undertaken in four suburban regions within the Gold Coast City. These four regions were selected based on their apparent differences in socioeconomic classification. The dates of estate development of all the regions were similar thus ensuring the fixtures and fittings within homes were relatively comparable.

In total, an initial end use study sample of 151 single detached residential households

was obtained. The extensive research sample was obtained through a multi-staged process of letters and door knocking. Selection of participants was based on a number of criteria including: household ownership status (renting/owning) and household makeup (i.e. number 
of householders, age of occupants, etc); willingness to be part of the research for a period of two years; acceptance of multiple water consumption monitoring periods and several surveys with potential interventions; as well as involvement in a household water appliance stock audit (Willis et al., 2009). Historical household volumetric readings for the consenting sample were also analysed to ensure that the recruited sample's water use frequency distribution was representative of the region and City. As a final note, the useable sample for the purposes of this specific mixed method study was 132, due to the requirement for aligned questionnaire survey responses, as detailed in a later section.

\subsection{End use smart metering approach}

Standard water meters in the Gold Coast study area were exchanged with Actaris CTS-5 high resolution water meters. These meters pulse at 72 counts/litre which accounts to a pulse read every $14 \mathrm{~mL}$ of water used. DataCell D-CZ21020 data loggers were attached to water meters to record end use water consumption data (Willis et al., 2010). Data loggers were set to record data points in ten (10) second intervals. Data were downloaded from data loggers manually with laptops via infrared cables. The data were then checked for validity with a two week timeframe selected for analysis. In home stock inventory surveys, water consumption behaviours and basic demographic descriptive statistic reports were undertaken to ascertain water devices and usage behaviours in households. The acquired end use data were analysed with the Trace Wizard ${ }^{\mathrm{TM}}$ software in order to disaggregate flow data into a repository of individual end use water consumption records for each home. Data analysis involves trained researchers conducting the end use analysis process of verifying signature traces for each water use activity occurring in the household, the stock and behavioural surveys aided this process. 


\subsection{Questionnaire development and survey}

In addition to monitoring water end use consumption, demographic and attitudinal surveys were developed and distributed to all the sampled households. The main purpose of the survey was to solicit respondent ratings for the two attitudinal constructs, namely CE and WC, and to obtain an understanding on the demographic characteristics of residential water consumers making up each household. Measurement items contained in the questionnaire evolved from the abovementioned literature review and factor operationalisation process (Tables 1 and 2). A five-point Likert-type measurement scale was adopted for the respondents' rating of attitudinal items, with 1 representing strongly disagree and 5 representing strongly agree. Postal mail was the method for questionnaire distribution. It is important to note that only one questionnaire survey was completed per household. The head of each household was requested to convene a meeting with other residents, and consultatively respond to the questionnaire items, thus providing a response which was representative of the group. In cases where members could not attend or were young children, they were requested to provide a perceived rating which reflects their perception of the household's overall attitude to the listed items. Data obtained from the survey together with the logged water meter data disaggregated into a repository of all end use events, were compiled into SPSS version 17.0 for the purpose of statistical analysis, as presented in the following section.

\section{Data analysis and results}

\subsection{Descriptive statistics}

Of the 151 surveys sent, a total of 132 usable responses were received, representing an effective response rate of $87 \%$. This response rate was high as participants had already consented to being a part of a two year end use study and had their water meters replaced with 
those of a higher resolution and loggers connected. It should be noted that only the water end use data from these usable 132 survey respondents was used in the subsequent analyses since this was a mixed method study, whereby both a completed questionnaire survey and water end use data was required.

The demographic characteristic of survey responses was classified based on household types and socioeconomic areas. In terms of household types, the majority were made up of small and large families (67\%), followed by couples (25\%). The remaining $8 \%$ was a mix of households with a single person, share house and family with border. The four research regions included in the sample were predominately from the middle class range (i.e. lower to upper middle class). Some socioeconomic descriptive variables have been provided in Table 4 to shed light on the characteristics of the sample.

[Insert Table 4]

Based on the data obtained from the 132 survey respondents, descriptive statistical analysis was firstly performed on factor measurement items to examine the mean, standard deviation, as well as the reliability of the measurement scale used in the questionnaire. The results are presented in Table 5. The Cronbach's Alpha coefficient of 0.91 calculated from the complete set of items indicates a high level of internal consistency (i.e. reliability) of the scale used in the survey (Hair et al., 2006).

[Insert Table 5] 


\subsection{Measurement model assessment}

In addition to assessing the consistency of the scale presented in the preceding section, Confirmatory Factor Analysis was employed to assess the scale's construct validity and unidimensionality. In essence, CFA is a way of testing how well a priori factor structure and its respective pattern of loadings match the actual data (Hair et al., 2006). CFA can be used to refine an existing theoretical perspective, support an existing structure, and test a known dimensional structure in an additional population (DiStefano and Hess, 2005). For the purpose of this study, CFA was used to confirm the developed factor structure (referred to as "measurement model") that represented the set of attitudes toward the environment and water conservation, respectively, for the study sample (Tables 1 and 2). To achieve this, CFA requires an assessment of model fit, and an indication of how well the hypothesised measurement model (i.e. the factors and associated indicators presented in Tables 1 and 2) represents the data obtained from the survey. This was conducted on the basis of five common model fit indices: normal chi-square $\left(\chi^{2} / d f\right)$; goodness-of-fit index (GFI); comparative-fit index (CFI); incremental-fit index; and root mean square error of approximation (RMSEA). To be considered as having an adequate fit, all the indices were measured against the following criteria: $\chi^{2} / d f<3.00$; GFI, CFI, and IFI $>0.90$; and RMSEA $<0.08$ (Hair et al., 2006).

CFA was conducted using AMOS version 17.0, employing the maximum likelihood estimation (MLE) method for parameter estimation. The initial results indicated that the measurement model did not fit the data well. To improve the model fit, a refinement procedure was carried out, which mainly involved removing items that had insignificant or low factor loading $(<0.50)$, and low reliability $\left(R^{2}<0.50\right)$. This procedure led to the elimination of items WC3, WC4 and WC5. Table 6 presents the results of the refined measurement model analysis, showing the loading, t-value and $R^{2}$ of each item along with the 
composite reliability and average variance extracted of each factor. As shown in the table, all of the remaining items have loadings on their respective factors greater than 0.50 , with all $t-$ values being significant at $p<0.001$, indicating convergent validity of the model (Hair et al., 2006). In terms of item reliability, several items had $R^{2}$ values lower than the common acceptable level of 0.50, suggesting potential for elimination. However, since their loadings were meaningful (greater than 0.50) and highly significant, these items were retained in the measurement model (Koufteros, 1999). Furthermore, both factors were shown to have a composite reliability well above 0.60 , and average variance extracted being greater than 0.50 (Bagozzi and Yi, 1988). The fit indices of this model (presented underneath Table 6) also show an acceptable level of fit according to the criteria mentioned above $\left(\chi^{2}=140.59\right.$; $d f=$ $76 ; \chi^{2} / d f=1.85 ; \mathrm{GFI}=0.86 ; \mathrm{CFI}=0.93 ; \mathrm{IFI}=0.94 ;$ RMSEA $\left.=0.08\right)$. Therefore, the model was deemed the final measurement model, as illustrated in Figure 1. The figure shows the model's structure of the factors and their associated items, correlation between both factors, and the final loadings of all items on their respective construct.

It should be further noted that the high correlation between the two factors $(0.95)$ indicated their ability to represent aligned concepts (Kline, 2005). However, combining them proved to weaken the model fit indices. Furthermore, the discriminate validity of the model (i.e. CE and WC existed as two separate factors rather than one) was supported by the significant Chi-Square difference statistic between the models with unconstrained and constrained (fixed at 1.00) correlation coefficients between the two factors (Koufteros, 1999). All of the above results suggested that this final measurement model (Figure 1) possesses adequate convergent validity (i.e. all items reliably represented their respective factor), unidimensionality (i.e. all items only represented their respective factor not the other) and discriminant validity (i.e. two factors rather than one). The final measurement model's underlying factor structure was therefore used in the subsequent analyses. 
[Insert Table 6]

[Insert Figure 1]

\subsection{Exploration of clusters}

Once the factor structure had been refined and confirmed by the CFA, all the retained items were used as a basis for determining whether there were any distinct groupings evident in the sample that shared similar patterns of ratings for both the concern for the environment and water conservation awareness and practice factors. To achieve this objective, cluster analysis was adopted. According to Hair et al. (2006), cluster analysis is an exploratory data analysis tool for solving classification problems. Its purpose is to categorise cases into groups or clusters so that each case is very similar to others in its clusters. Two major stages of the cluster analysis procedure were carried out in this research: (1) partitioning; and (2) interpretation. The partitioning stage is the process of determining the number of clusters that may be developed. The interpretation stage is the process of understanding the characteristics of each cluster and developing a name or label that appropriately defines its nature (Hair et al., 2006). SPSS version 17.0 for Windows was employed to perform the analysis.

\subsubsection{Number of clusters and final centroids}

The hierarchical cluster analysis procedure, incorporating Ward's method, was conducted on all fourteen (14) items included in the final measurement model as presented in Figure 1. This clustering procedure involves a combination of the objects into a hierarchy or a treelike structure, as represented by a dendrogram. A dendrogram provides an indication of heterogeneity change (average within-cluster distance) for all possible combinations of 
clusters. A decision on the final number of clusters is usually based on the combinations that do not yield a substantial increase in heterogeneity (Hair et al., 2006). From an inspection of the dendrogram, it was found that a division of two clusters represented the best solution. The final centroids of the two clusters based on the fourteen items are plotted in Figure 2. The cluster centroids are the mean values for each item that represent the general characteristics of a cluster (Yeung et al., 2003). Additionally, the results from One-way Analysis of Variance (ANOVA) showed that the final centroids of both clusters were significantly different across all items.

[Insert Figure 2]

\subsubsection{Interpretation of clusters}

The characteristics of both uncovered clusters were interpreted through the cluster profiles presented in Figure 2. From the figure, it can be observed that the centroids within Cluster 1 are consistently very high across all items, indicating that this group of respondent had a very high concern for environment and water conservation. Thus Cluster 1 was labelled VHC. For

Cluster 2, the centroids value for both factors ranged between moderate to high levels, suggesting that this group of respondents had a moderate to high level of concern for the environment and water conservation. Hence, Cluster 2 was labelled MHC. To better understand the characteristics of the clusters, socio-demographic information for the households categorised within each cluster was subsequently examined with the goal to extract any distinctive features that could explain the two groups.

Examination of the demographic information for both clusters revealed that the VHC group has a higher proportion of small and large family households (74\%) than that of the MHC cluster (62\%). On the other hand, the percentage of households with couples in the 
VHC group (21\%) was lower than that of the MHC group (27\%). The average household lot sizes for the two clusters were very similar, being $683 \mathrm{~m}^{2}$ and $691 \mathrm{~m}^{2}$, for MHC and VHC, respectively. The VHC cluster had a lower average income (AUD\$1584; USD\$1300 May 2010) than the MHC cluster (AUD\$1744; USD\$1431). Whilst, this difference is not statistically significant due to the relatively small sample size $(F=1.370 ; p=0.244)$, it could provide some indication that environmental and water conservation concern may become less important to greater proportions of people in the upper middle and higher classes. An attempt to shed some light on the influence of socioeconomic factors on the relationship between attitudes and water consumption behaviours is provided later.

\subsection{Water consumption end use analysis}

\subsubsection{Overall end use consumption}

The breakdown of end use water consumption for the total sampled households in the Gold Coast $(n=132)$ is presented in Figure 3. The overall average consumption for the sampled Gold Coast households ( $\mathrm{n}=132$ ) was $152.3 \mathrm{~L} / \mathrm{p} / \mathrm{d}$. It should be noted, that while attitude ratings and water end use comparisons are made at the household entity level, total water consumption and end use break downs are necessarily presented as $\mathrm{L} / \mathrm{p} / \mathrm{d}$ in order to level consumption volumes considering household size. The highest end use is showering, with each person consuming just over 47 litres of water per day or $31 \%$ of total use. The next highest end use is clothes washing accounting for $20 \%$ of total consumption or $30 \mathrm{~L} / \mathrm{p} / \mathrm{d}$. Tap use, toilet flushing and irrigation follow with end use percentages of $17 \%, 14 \%$ and $12 \%$, respectively. Bath use, dishwashing and leaks make up a small component of water end use with percentages ranging from $1 \%$ to $4 \%$. Figure 4 demonstrates the end use water consumption breakdown for each of the measured 132 households. 
[Insert Figure 3]

[Insert Figure 4]

\subsubsection{Clustered water end use consumption}

Two attitudinal clusters for the sampled households, namely VHC and MHC, were determined earlier based on the household residential perceptions regarding their concern for environment and water conservation awareness and practice. The VHC cluster denotes the group of households with a very high level of concern, whereas the MHC cluster represents the group with a moderate level of concern for the environment and water conservation awareness and practice. Further examination and comparison of the end use consumption levels, between the two clusters, could thus provide a basis for understanding the relationship between the herein measured environmental and water conservation attitudinal levels of concern and the actual end usage of water. To achieve this, the flow trace analysed average daily per capita end use consumption (i.e. L/p/d) for each household associated with the two extracted clusters (i.e. VHC and MHC) was assigned and compared.

Figure 5 shows the breakdown of average daily per capita consumption (L/p/d) of the households in the VHC cluster $(\mathrm{n}=54)$. The VHC average total water use was $128.2 \mathrm{~L} / \mathrm{p} / \mathrm{d}$, which is less than that for the combined 132 household sample $(152.3 \mathrm{~L} / \mathrm{p} / \mathrm{d})$. When considering individual end use activities, it was found that the volumetric consumption for all categories was lower than that of the total sample, with the exception of dishwasher. It can be further observed that the proportion of average daily per capita consumption (i.e. percentage) of most end use categories between the VHC cluster and the total sample is similar. However, of note is the proportion of irrigation use for the VHC cluster (8\%), which is considerably less than that of the total sample (12\%); as discussed the lot sizes of the two clusters is not 
significantly different. Figure 6, presents the VHC clusters' descending profile for each individual households' water end use consumption breakdown, indicating that the majority of households in this sub-sample consumed water less than $150 \mathrm{~L} / \mathrm{p} / \mathrm{d}$. Two excessively high users are present, whose average consumption was in the order of $350 \mathrm{~L} / \mathrm{p} / \mathrm{d}$. These two outliers potentially represent households whose reported attitudes do not adequately reflect their actual behaviours.

[Insert Figure 5]

[Insert Figure 6]

The break down of average daily per capita consumption (L/p/d) for the households in the MHC cluster ( $\mathrm{n}=78$ ) is presented in Figure 7. It can be observed that the proportion of all the average end use categories of this cluster is similar to that of the total sample presented in Figure 3. For this cluster, the average total water use was $169.0 \mathrm{~L} / \mathrm{p} / \mathrm{d}$, being higher than that of the total 132 sample consumption $(152.3 \mathrm{~L} / \mathrm{p} / \mathrm{d})$. Similarly, the end use consumption for all categories, except dishwasher, is also higher than that of the total sample. Figure 8 presents the MHC clusters' descending profile for each individual households' water end use consumption break down. It can be seen that more than half of the households in this subsample consumed more than $150 \mathrm{~L} / \mathrm{p} / \mathrm{d}$.

[Insert Figure 7]

[Insert Figure 8] 


\subsubsection{Clustered comparative analysis}

Results from the preceding section provided illustrative evidence that end use water consumption varies depending on the environmental attitudes of consumers. Further investigation was undertaken to determine the level of statistical difference for each end use category. To achieve this, an independent sample $t$-test was carried out using the two extracted clusters as input samples. The results from this test, as presented in Table 7 show that total water consumption volumes for these two clusters are statistically different, with the VHC cluster having $24.1 \%$ lower consumption $(128.2 \mathrm{~L} / \mathrm{p} / \mathrm{d})$ than that of the MHC $(169.0$ $\mathrm{L} / \mathrm{p} / \mathrm{d}$ ). Furthermore, consumption levels for the four defined discretionary end use categories (i.e. shower, clothes washer, tap and irrigation) are all significant at 0.05 level, suggesting that there is a relationship between the households' levels of water conservation and environmental concern, and actual water end use consumption. Irrigation represents the most significant difference, where the VHC cluster (i.e. $10.8 \mathrm{~L} / \mathrm{p} / \mathrm{d}$ ) has a $12.2 \mathrm{~L} / \mathrm{p} / \mathrm{d}$ or $53.0 \%$ reduction from the MHC cluster (i.e. 23.0L/p/d). Expectedly, Table 7 also shows that the two non-discretionary end uses such as dishwasher and toilet, which are largely not affected by household behaviours due to their mechanical nature, were not significantly different. A discussion on total, behaviourally influenced water consumption end use differences, along with an exploratory analysis on the socio-demographic factors underpinning these differences, is outlined below.

[Insert Table 7] 


\section{Discussion}

\subsection{Overview on water consumption and attitudes}

Cluster analysis results indicated that survey respondents could be classified into two environmental attitudinal groups, namely VHC and MHC. Residents clustered in the VHC group reported very high levels of understanding and concern for the environment and water conservation, whereas those in the MHC cluster reported only a moderate level. Total water consumption, as well as the disaggregated water end uses categories that sum to this total, were aligned with household attitudinal ratings and compared. Three propositions were established and the calculated statistical results support the view that water end use consumption levels can significantly differ depending on the resident's level of concern toward the environment and water conservation. Both the VHC and MHC groups displayed differing end use water consumption levels and possessed divergent characteristics. The following sections provide further discussion, which outlines the supportive evidence for the listed propositions as well as proposes some of the underlying factors contributing to the current situational context.

\subsubsection{Relationship between attitudes and total water consumption}

It was hypothesised in this research that households with higher levels of environmental concern and attitude towards water conservation will consume significantly less water in total. The analysis results provided empirical evidence which supports the first proposition (Proposition 1) by demonstrating that the VHC cluster households consumed significantly less water than the MHC cluster households. This finding provides further support to previously reported research studies (Nancarrow et al., 1996) by revealing the link between positive attitudes and commitment towards the environment and water conservation. These 
supportive attitudes often result in improved water conservation behaviours which, in turn, lead to lower levels of total water consumption in households.

\subsubsection{Relationship between attitudes and behaviourally influenced end use consumption}

The smart metering approach employed enabled the monitoring of water end use events. Of these end uses, five were considered to be strongly influenced by behavioural aspects: shower, clothes washer, tap, bathtub and irrigation. Results from the clustered comparative analysis indicated significant differences in water consumption in all behaviourally influenced end uses, with the exception of bathtub, demonstrating that VHC residents consumed significantly less water in these end uses than the MHC residents. This finding provides empirical support for Proposition 2a, demonstrating that households with higher levels of environmental concern and positive attitude towards water conservation have significantly lower levels of consumption in behaviourally influenced water end uses. It should be noted that the reason water use in bathing, despite being considered moderately influenced by behaviours, showed no significance difference between the two clusters could be due to the fact that only a few households in the sample undertook this activity, thus making statistical comparisons less reliable.

Importantly, the above findings imply that there is a positive relationship between attitudes towards the environment and water conservation and water end use consumption across behaviourally influenced end uses. As discretionary end use consumption varies entirely based on the decision of water users to consume beyond what is necessary, those water users with positive attitudes towards environmental sustainability would tend to be more cautious when using water than those who do not highly value or consider the environment. Examples of sustainable activities potentially undertaken by the VHC residents

could include: (1) showering over smaller durations with high efficiency showerheads; (2) 
washing clothes in water efficient washing machines and residents waiting until they have a full load before commencing washing; (3) only watering outdoors when absolutely necessary; (4) not continuously running taps for rinsing dishes; and (5) turning off taps when brushing teeth or washing vegetables.

The potential water savings achievable across certain end uses, through transforming households' attitudes, is highly evident (Table 7). Improving the attitudes of MHC residents could mean the reduction in water consumption across discretionary end uses, ranging from approximately $18.6 \%$ to $53.0 \%$. Such savings, when translated across entire cities, would ensure greater urban water security in a time where climate variability is becoming more prevalent. This benefit, however, needs to be further examined in future research through a longitudinal study implementing and monitoring the influence of education programs to improve the attitudes of water users.

\subsubsection{Relationship between attitudes and non-discretionary end use consumption}

Because non-discretionary end uses are those water use activities that tend to be consumed to satisfy basic need or function without being much affected by the users' behaviour, it was hypothesised in this research that there will be no significant differences in non-discretionary water end uses between households having different attitudes towards the environment and water conservation (Proposition 2b). The two end use events that considered as nondiscretionary are toilet and dishwasher. As anticipated, these end uses did not have any significant difference across the VHC and MHC clusters, thus providing empirical support for this proposition. This finding demonstrates that differences in attitudes towards the

environment and water conservation are not associated with the consumption of nondiscretionary water end uses. 
Leakage was not classified as either a discretionary or non-discretionary end use. It is worthwhile noting that the levels of leakage did not differ between the two clusters. Some visible components of leakage such as rectifying continuously running cisterns are affected by behaviours, but less visible leakage was not considered to be affected by behaviours. Due to the small number of households with significant leakage, and the resulting low volumes within each cluster, it is difficult to reliably assess this relationship in the present study. Nonetheless, some of the urban water researchers associated with this study is examining such an issue in a separate investigation (Britton et al., 2008; Britton et al., 2009).

\subsection{Linking socio-demographic variables with attitudes}

In addition to examining the relationship between attitudes and water consumption, the interpretation of clusters revealed some demographic characteristics that had higher representation in each identified cluster. The VHC residents consisted of a larger proportion of families whereas the MHC cluster had a lower proportion of families and higher proportion of singles and couples. This suggests that families may have higher awareness or understanding of the environment and water conservation practices and higher application of such knowledge. The study indicated that there was no difference between the average lot

sizes of the two clusters, indicating that irrigable area was not a contributing factor to the difference in irrigation end use volumes. As discussed previously there was a difference between the average incomes for the two clusters, albeit not statistically significant. Nonetheless, this difference does provide some persuasion for future research to explore whether households that have higher disposable incomes (i.e. upper middle and high classes) are more likely to have less regard for resource conservation, particularly low cost resources such as potable water.

Other studies have indicated that affluence may play a significant part in higher water consumption behaviours (CSIRO, 2002; Kim et al., 2007; Kenney et al., 2008). In summary, 
whilst the authors acknowledge that a wide range of other contributing factors, beyond environmental/water attitudes such as pricing or demographics, contribute to water consumption behaviours, the study provides strong indications that attitudes play a predominant role in water conservation. Further research on attitudes towards environment and water conservation across different socio-economic groups could provide additional insight into domestic water consumption behaviour and would assist in triggering the development of targeted awareness messages.

\section{Conclusions and implications}

This paper presented findings from a component of the GCWSEU. The herein discussed component of the greater research program was focused on establishing if attitudes influence a range of end use water consumption levels; such a mixed method study has not been reported in the literature. The research findings provided empirical support to the propositions that pro-environmental and water conservation attitudes result in household total water savings, and across the majority of discretionary end uses, respectively.

Two attitudinal constructs, concern for the environment and water conservation awareness and practice, were statistically validated following a measurement reliability and scale analysis process. Subsequently, cluster analysis uncovered two distinct groups of households, being those with very high concern (VHC) and those with moderate to high (MHC) concern. Smart meters were utilised to collect high resolution (0.014 L/pulse) flow data, which was then disaggregated into end uses for the 132 households involved in the study. Three research propositions were developed and tested. Overall, it was established that strong positive environmental and water conservation attitudes resulted in significantly $(p<$ 0.05) lower total water consumption as well as for the behaviourally influenced end use categories (i.e. shower, clothes washing, irrigation and tap use). Bath use was not affected by 
attitudes potentially due to the small number of household residents partaking in this activity. Non-discretionary toilet and dishwasher use was not influenced by attitudes as predicted. Leakage being categorised as neither a discretionary or non-discretionary use was also not shown to be impacted by attitudes; however, examining this end use category was outside the scope of this research. Residents with a high level of concern or attitude towards the environment had a higher representation of families than couples and slightly higher incomes, although this was not at a significant level.

The results from this research provide water demand management professionals with an understanding on where educational programs should be targeted to obtain the highest effective household water savings. Significant water savings in high end uses within homes can be achieved if pro-environmental attitudes can be effectively instilled. This research supports the development of directed awareness information focused on improving the current level of understanding of sustainable shower, clothes washing, irrigation and tap use behaviours. Such targeted programs will result in significant reductions in water consumption within residential households. The study provides empirical evidence to support the view that if society at large values water and is actively concerned with how it is being consumed, significant reductions in consumption levels can occur. This in turn will lead to a reduced requirement for environmentally adverse water supply alternatives (e.g. desalination plants) to support demand. As a final note, the findings and herein described research methods could also be applied to investigate relationships between attitudes and resources (i.e. water, energy and materials) and conservation in the commercial and industrial sectors.

\section{Acknowledgements}

The research forms a component of the Gold Coast Watersaver End Use (GCWSEU) study, a research collaborative between Griffith University and Gold Coast Water under an Australia 
Research Council (ARC) grant. Gold Coast Water is acknowledged for their financial and inkind support to the herein described study. The Institute for Sustainable Futures, Wide Bay Water Corporation and the Queensland Water Directorate are also acknowledged for their involvement in the research collaborative. Lastly, the authors appreciate the invaluable comments from the anonymous reviewers of an earlier version of this paper. 


\section{References}

ACTCOSS \& CCSERAC (2003) Saving our Water Resources and equitable and sustainable policy for the ACT. ACT Council of Social Services and Conservation Council of the South East Region and Canberra. Canberra.

Bagozzi, R. P. \& Yi, Y. (1988) On the evaluation of structural equation models. Journal of the Academy of Marketing Science, 16, 74-94.

Barrett, G. (2004) Water conservation: the role of price and regulation in residential water consumption. Economic Papers: A Journal of Applied Economics and Policy, Vol. 23:3, pp. 271-285.

Bates, B. C., Kundzewicz, Z. W., Wu, S. \& Palutikof, J. P. (2008) Climate Change and Water - IPCC Technical Paper VI. Intergovernmental Panel of Climate Change (IPCC) Secretariat, Geneva.

Bechtel, R., Corral-Verdugo, V. \& Pinheiro, J. (1999) Environmental belief systems: United States, Brazil, and Mexico. Journal of Crosscultural Psychology, Vol 30, pp. 122128.

Birrell, B., Rapson, V. \& Smith, F. (2005) Impact of Demographic Change and Urban Consolidation on Domestic Water Use. Water Services Association of Australia Inc, Melbourne.

Britton, T., Cole, G., Stewart, R. \& Wisker, D. (2008) Remote diagnosis of leakage in residential households. Water: Journal of Australian Water Association, Vol 35:6, pp. 89-93.

Britton, T., Stewart, R. A. \& O'Halloran, K. (2009) Smart metering providing the foundation for post meter leakage management. IWA Specialist Conference - Efficient 2009, 25th to 28th October 2009. Sydney, Australia.

Brooks, D. B. (2002) Water: Local-Level Management. Ottawa: International Development Research Centre.

Brooks, D. B. (2006) An Operational Definition of Water Demand Management. International Journal of Water Resources Development, Vol 22:4, pp. 521 - 528.

Commonwealth of Australia (2008a) Drought. Online article, accessed 20/03/08, available at http://www.bom.gov.au/lam/climate/levelthree/c20thc/drought.htm Bureau of Meteorology.

Commonwealth of Australia (2008b) Living with Drought. online article, available at http://www.bom.gov.au/climate/drought/livedrought.shtml Accessed 14/03/08. Bureau of Meteorology.

Cordell, D., Robinson, J. \& Loh, M. (2003) Collecting residential end use data from primary sources: do's and dont's. Institute For Sustainable Futures, University of Technology, Sydney,.

Corral-Verdugo, Bechtel, R. \& Fraijo-Sing, B. (2003) Environmental beliefs and water conservation: An empirical study. Environmental Psychology, Vol 23, pp. 247-257.

CSIRO (2002) Perth domestic water-use study household ownership and community attitudinal analysis. NSW, Australian Research Centre for Water in Society CSIRO Land and Water

DECC (2007) Who Care About Water and Climate Change in 2007? Department of Environment and Climate Change. November 2007.

Deverill, P. (2001) Sharing It Out - Introducing Water Demand Strategies for Small Towns (London and Loughborough). Water and Environmental Health. 
DiStefano, C. \& Hess, B. (2005) Using confirmatory factor analysis for construction validation: an empirical review. Journal of Psychoeducational Assessment, 23, 225241.

Gilg, A. \& Barr, S. (2006) Behavioural attitudes towards water saving? Evidence from a study of environmental actions. Ecological Economics, Vol 57, pp. 400-414.

Gleick, P.H. (1996) Basic water requirements for human activities: meeting basic needs. Water International 21, Vol. 21:2, pp. 83-92.

Giurco, D., Carrard, N., McFallan, S., Nalbantoglu, M., Inman, M., Thornton, N. \& White, S. (2008) Residential end-use measurement guidebook: a guide to study design, sampling and technology. Prepared by the Institute for Sustainable Futures, UTS and CSIRO for the Smart Water Fund, Victoria.

Gold Coast Water (2008) Internal discussion on survey investigations. IN WILLIS, R. (Ed.) Gold Coast.

Hair, J. F., Black, W. C., Babin, B. J., Anderson, R. E. \& Tatham, R. L. (2006) Multivariate Data Analysis, 6th edn, Pearson Prentice Hall, Upper Saddle River, N.J.

Hassell, T. \& Cary, J. (2007) Promoting Behavioral Change in Household Water Consumption: Literature Review. Victoria, Smart Water.

Heinrich, M. (2007) Water End Use and Efficiency Project (WEEP) - Final Report. BRANZ Study Report 159. Judgeford, New Zealand, Branz.

Hurlimann, A. C. (2008) Community Attitudes to Recycled Water Use: an Urban Australian Case Study Part 2. Salisbury, SA, CRC for Water Quality and Treatment Project No. 201307.

Inman, D. \& Jeffrey, P. (2006) A review of residential water conservation tool performance and influences on implementation effectiveness. Urban Water Journal, Vol 3:3, pp. 127-143.

Kenney, D., Goemans, C., Klein, R., Lowrey, J. \& Reidy, K. (2008) Residential water demand management: lessons from Aurora, Colorado. Journal of the American Water Resources Association, Vol. 44:1, pp. 192-207.

Kim, S. H., Choi, S. H., Koo, J. K., Choi, S. I. \& Hyun, I. H. (2007) Trend analysis of domestic water consumption depending upon social, cultural, economic parameters. Water Science and Technology: Water Supply, Vol 7:5-6, pp. 61-68.

Kline, R. B. (2005) Principles and Practice of Structural Equation Modeling, New York, Guilford Press.

Korfiatis, K. J., Hovardas, T. \& Pantis, J. D. (2004) Determinants of Environmental Behavior in Societies in Transition: Evidence from five European Countries. Population and Environment, Vol. 25:6.

Koufteros, X. (1999) Testing a model of pull production: a paradigm for manufacturing research using structural equation modeling. Journal of Operations Management, 17, 467-488.

Loh, M. \& Coghlan, P. (2003) Domestic Water Use Study. Perth, Water Corporation.

Mayer, P. W. \& DeOreo, W. B. (1999) Residential End Uses of Water. Aquacraft, Inc. Water Engineering and Management, Boulder, CO.

Middlestadt, S., Grieser, M., Hernandez, O., Tubaishat, K., Sanchack, J., Southwell, B. \& Schwartz, R. (2001) Turning Minds on and Faucets Off: Water Conservation Education in Jordanian Schools. The Journal of Environmental Education, Vol 32:2, pp. 37-45.

Nancarrow, B. E. (2002) Regulations and Restrictions: A Community Perspective. Water Symposium Session 'Total Water Management Tools and Decisions Making'. Water Symposium, 7-9 October 2002, Parliament House, Western Australia. 
Nancarrow, B. E., Smith, L. M. \& Syme, G. J. (1996) The ways people think about water. Journal of Environmental Systems, Vol 25:1, Baywood Publishing Company, Inc, Amityville.

Nancarrow, B. E. \& Syme, G. J. (1989) Improving Communication with the Public on Water Industry Policy Issues. UWRAA Research Report No. 6.

Nieswaidomy, M. L. \& Molina, D. J. (1989) Comparing Residential Water Demand Estimates under Decreasing and Increasing Block Rates Using Household Data. Land Economics, Vol 65: 3, pp. 280-289.

Po, M., Nancarrow, B. E., Leviston, Z., Porter, N. B., Syme, G. J. \& Kaercher, J. D. (2005) Predicting Community Behaviour in Relation to Wastewater Reuse. CSIRO, Canberra.

Renwick, M. A. \& Archibald, S. O. (1998) Demand-side management policies for residential water use: who bares the conservation burden? Land Economic, Vol 74, pp. 343-359.

Renwick, M. A. \& Green, R. D. (2000) Do Residential Water Demand Side Management Policies Measure Up? An Analysis of Eight California Water Agencies. Journal of Environmental Economics and Management, Vol 40, pp. 37-55.

Roberts, P. (2005) Yarra Valley Water 2004 Residential End Use Measurement Study. Melbourne, Yarra Valley Water.

Stewart, R.A. Willis, R. Giurco, D. Panuwatwanich, K. \& Capati, G. (2010) Web-based knowledge management system: linking smart metering to the future of urban water planning. Australian Planner, 47(2), 66-74.

Savenije, G. H. H. \& van der Zaag (2002) Water as an economic good and demand management: paradigms and pitfalls. Water International, Vol 27:1, pp. 98-104.

Syme, G. \& Nancarrow, B. (1992) Predicting public involvement in urban water management and planning. Environment and Behaviour, Vol 24. pp. 738-758.

Syme, G. J., Nancarro, B. E. \& Seligman, C. (2000) The Evaluation of Information Campaigns to Promote Voluntary Household Water Conservation. Evaluation Review, Vol 24:6, pp. 539-578. Sage Publications.

Tate, D. M. (1993) An overview of water demand management and conservation. Vision 21: Water for People, Geneva: Water Supply and Sanitation Collaborative Council).

Worthington, A.C. and Hoffman, M. (2008) An empirical survey of urban water demand modelling, Journal of Economic Surveys, Vol. 22:5, pp. 842-871.

White, S., Turner, A., Fane, S. \& Giurco, D. (2007) Urban water supply-demand planning: a worked example. 4th IWA Specialist Conference on Efficient Use and Management of Urban Water Supply. Jeju, Korea.

WHO (2005) Minimum water quantity needed for domestic use in emergencies. WHO Technical Notes for Emergencies, World Health Organization, Switzerland.

Willis, R., Stewart, R., Panuwatwanich, K., Capati, B. \& Giurco, D. (2009) Gold Coast Domestic Water End Use Study. Water: Journal of Australian Water Association Vol 36:6, pp. 79-85.

Willis, R., Stewart, R. A., Panuwatwanich, K., Jones, S. \& Kyrakides, A. (2010) Alarming visual display monitors affecting shower end use water and energy conservation in Australian residential households. Journal of Resources, Conservation and Recycling, 54(12), 1117-1127.

Willis, R. M., Stewart, R. A., Williams, P. R., Hacker, C.H. Emmonds, S. C. \& Capati, G. (2011) Residential potable and recycled water end uses in a dual reticulated supply system, Desalination, (in-press), doi:10.1016/j.desal.2011.01.022.

Yeung, A. C. L., Chan, L. Y. \& Lee, T. S. (2003) An empirical taxonomy for quality management systems: a study of the Hong Kong electronics industry. Journal of Operations Management, 21, 45-62. 


\section{Figure Captions:}

Figure 1. CFA Model.

Figure 2. Profiles of clusters’ final centroids.

Figure 3. Average daily per capita consumption per end use: total sample $(n=132)$.

Figure 4. Household daily per capita consumption distribution with water end use breakdown: total sample $(\mathrm{n}=132)$.

Figure 5. Average daily per capita consumption: VHC cluster $(\mathrm{n}=54)$.

Figure 6. Household daily per capita consumption distribution profile: VHC cluster ( $n=54)$.

Figure 7. Average daily per capita consumption: MHC cluster (n=78).

Figure 8. Household daily per capita consumption distribution profile: MHC cluster (n=78). 
Table 1. Measurement items for concern for environment factor.

\begin{tabular}{|c|c|c|c|}
\hline \multicolumn{4}{|c|}{ Concern for environment (CE) } \\
\hline Code & Measurement item & Description & References \\
\hline CE1 & $\begin{array}{l}\text { Protection of natural } \\
\text { environment for future } \\
\text { generations }\end{array}$ & $\begin{array}{l}\text { Examining the way in which } \\
\text { individuals view the } \\
\text { importance of protecting the } \\
\text { natural environment. }\end{array}$ & $\begin{array}{l}\text { Corral-Verdugo et al. } \\
\text { (2003); } \\
\text { CSIRO (2002). }\end{array}$ \\
\hline CE2 & $\begin{array}{l}\text { Community responsibility } \\
\text { for reducing water } \\
\text { consumption }\end{array}$ & $\begin{array}{l}\text { Enquiry of community } \\
\text { responsibility for conserving } \\
\text { water sources by reducing } \\
\text { consumption. }\end{array}$ & $\begin{array}{l}\text { CSIRO (2002); } \\
\text { Nancarrow (2002); } \\
\text { Corral-Verdugo et al. } \\
\text { (2003); } \\
\text { DECC (2007). }\end{array}$ \\
\hline CE3 & $\begin{array}{l}\text { Concern for environmental } \\
\text { problems }\end{array}$ & $\begin{array}{l}\text { Investigation of care or } \\
\text { concern for the general } \\
\text { environment }\end{array}$ & $\begin{array}{l}\text { Hurlimann (2008) ; } \\
\text { Corral-Verdugo et al. } \\
\text { (2003); } \\
\text { DECC (2007). }\end{array}$ \\
\hline CE4 & $\begin{array}{l}\text { Joint responsibility of } \\
\text { government and } \\
\text { community to ensure water } \\
\text { security }\end{array}$ & $\begin{array}{l}\text { Inquest into water security } \\
\text { being the responsibility of } \\
\text { both the government and the } \\
\text { community. }\end{array}$ & $\begin{array}{l}\text { Nancarrow (2002); } \\
\text { DECC (2007). }\end{array}$ \\
\hline CE5 & $\begin{array}{l}\text { Acknowledge water as } \\
\text { being a valuable resource }\end{array}$ & $\begin{array}{l}\text { Query of the scarcity of } \\
\text { water and acknowledgement } \\
\text { of its value as a resource. }\end{array}$ & $\begin{array}{l}\text { CSIRO (2002); } \\
\text { Hurlimann (2008); } \\
\text { Nancarrow et al. (1996); } \\
\text { Nancarrow (2002); } \\
\text { Corral-Verdugo et al. } \\
\text { (2003). }\end{array}$ \\
\hline CE6 & $\begin{array}{l}\text { Acknowledge role in } \\
\text { creating a sustainable } \\
\text { water future }\end{array}$ & $\begin{array}{l}\text { Comprehension of the role } \\
\text { of people as consumers and } \\
\text { the need to use resources } \\
\text { sustainably to ensure } \\
\text { availability in the future. }\end{array}$ & Hurlimann (2008) \\
\hline CE7 & $\begin{array}{l}\text { Valuing recycling, } \\
\text { composting and other } \\
\text { environmentally } \\
\text { sustainable activities }\end{array}$ & $\begin{array}{l}\text { Evaluation the value of } \\
\text { recycling, composting and } \\
\text { other environmentally } \\
\text { sustainable activities to } \\
\text { consumers. }\end{array}$ & $\begin{array}{l}\text { Gilg and Barr (2006); } \\
\text { DECC (2007); } \\
\text { Korfiatis et al. (2004). }\end{array}$ \\
\hline CE8 & $\begin{array}{l}\text { Acknowledge humans role } \\
\text { as caretaker for } \\
\text { environment }\end{array}$ & $\begin{array}{l}\text { Viewpoint on humans being } \\
\text { responsible for sustaining } \\
\text { the environment in its } \\
\text { natural form }\end{array}$ & $\begin{array}{l}\text { Corral-Verdugo et al. } \\
\text { (2003); } \\
\text { Syme et al. (2000). }\end{array}$ \\
\hline
\end{tabular}


Table 2. Measurement items for water conservation awareness and practice factor.

\begin{tabular}{|c|c|c|c|}
\hline Code & Measurement item & Description & References \\
\hline WC1 & $\begin{array}{l}\text { Awareness of opportunities to } \\
\text { save water in household }\end{array}$ & $\begin{array}{l}\text { Understanding of the } \\
\text { numerous opportunities or } \\
\text { practices to conserve water } \\
\text { in the household. }\end{array}$ & $\begin{array}{l}\text { Nancarrow and Syme } \\
\text { (1989); CSIRO (2002); } \\
\text { Gilg and Barr (2006); } \\
\text { DECC (2007); } \\
\text { Mayer and DeOreo (1999). }\end{array}$ \\
\hline WC2 & $\begin{array}{l}\text { Awareness of the water } \\
\text { saving benefits of retrofitting } \\
\text { to water efficient fixtures and } \\
\text { appliances }\end{array}$ & $\begin{array}{l}\text { Examining the } \\
\text { understanding of the } \\
\text { reduction in water use } \\
\text { which can be achieved } \\
\text { through the application of } \\
\text { water efficient fixtures and } \\
\text { devices. }\end{array}$ & $\begin{array}{l}\text { Nancarrow and Syme } \\
\text { (1989); CSIRO (2002); } \\
\text { Heinrich (2007); } \\
\text { Mayer and DeOreo (1999). }\end{array}$ \\
\hline WC3 & $\begin{array}{l}\text { Water meter reading } \\
\text { competency }\end{array}$ & $\begin{array}{l}\text { Query of the ease of reading } \\
\text { the household water meter } \\
\text { and understanding the } \\
\text { values. }\end{array}$ & Gold Coast Water (2008) \\
\hline WC4 & Monitoring of water use & $\begin{array}{l}\text { Analysis of perception of } \\
\text { knowing and monitoring } \\
\text { how much water is used. }\end{array}$ & $\begin{array}{l}\text { CSIRO (2002); } \\
\text { DECC (2007); } \\
\text { Heinrich (2007). }\end{array}$ \\
\hline WC5 & $\begin{array}{l}\text { Awareness of the relationship } \\
\text { between behaviour and water } \\
\text { consumption }\end{array}$ & $\begin{array}{l}\text { Enquiry on the relationship } \\
\text { between water use activities } \\
\text { and actual water } \\
\text { consumption. }\end{array}$ & $\begin{array}{l}\text { Nancarrow (2002); } \\
\text { Gilg and Barr (2006); } \\
\text { DECC (2007). }\end{array}$ \\
\hline WC6 & Water saving knowhow & $\begin{array}{l}\text { Examination of the } \\
\text { application of activities to } \\
\text { save water in the home. }\end{array}$ & $\begin{array}{l}\text { Middlestadt et al. (2001); } \\
\text { CSIRO (2002); } \\
\text { DECC (2007). }\end{array}$ \\
\hline WC7 & $\begin{array}{l}\text { Perception on efficiency of } \\
\text { household water use } \\
\text { practices/behaviours }\end{array}$ & $\begin{array}{l}\text { Exploring the perceptions of } \\
\text { respondents on their } \\
\text { practices or behaviours } \\
\text { which contribute to being an } \\
\text { efficient water user. }\end{array}$ & $\begin{array}{l}\text { CSIRO (2002); } \\
\text { Gilg and Barr (2006). }\end{array}$ \\
\hline WC8 & $\begin{array}{l}\text { Seeking continuous savings in } \\
\text { water consumption over } \\
\text { longer term }\end{array}$ & $\begin{array}{l}\text { Determination on water } \\
\text { conservation being a long or } \\
\text { short term consideration. }\end{array}$ & $\begin{array}{l}\text { Syme et al. (2000); } \\
\text { CSIRO (2002); } \\
\text { DECC (2007). }\end{array}$ \\
\hline WC9 & Regular reads water meter & $\begin{array}{l}\text { Need work around } \\
\text { understanding \& monitoring } \\
\text { consumption with use of } \\
\text { water meters. }\end{array}$ & Gold Coast Water (2008) \\
\hline
\end{tabular}


Table 3. Results from completed domestic end use studies

\begin{tabular}{|c|c|c|c|c|c|c|c|c|}
\hline \multirow[t]{2}{*}{$\begin{array}{l}\text { End use } \\
\text { category }\end{array}$} & \multicolumn{2}{|c|}{$\begin{array}{l}\text { USA (1999) } \\
\text { Mayer \& } \\
\text { DeOreo }\end{array}$} & \multicolumn{2}{|c|}{$\begin{array}{l}\text { Perth (2003) } \\
\text { Loh \& Coghlan }\end{array}$} & \multicolumn{2}{|c|}{$\begin{array}{l}\text { Melbourne } \\
\text { (2005) } \\
\text { Roberts }\end{array}$} & \multicolumn{2}{|c|}{$\begin{array}{l}\text { Auckland (2007) } \\
\text { Heinrich }\end{array}$} \\
\hline & $\mathrm{L} / \mathrm{p} / \mathrm{d}$ & Percent & $\mathrm{L} / \mathrm{p} / \mathrm{d}$ & Percent & $\mathrm{L} / \mathrm{p} / \mathrm{d}$ & Percent & $\mathrm{L} / \mathrm{p} / \mathrm{d}$ & Percent \\
\hline Clothes washer & 56.8 & $8.7 \%$ & 42.0 & $13 \%$ & 40.4 & $19 \%$ & 39.9 & $24 \%$ \\
\hline Shower & 43.9 & $6.8 \%$ & 51.0 & $15 \%$ & 49.1 & $22 \%$ & 44.9 & $27 \%$ \\
\hline Tap & 41.3 & $6.3 \%$ & 24.0 & $7 \%$ & 27.0 & $12 \%$ & 22.7 & $14 \%$ \\
\hline Dishwasher & 3.8 & $0.6 \%$ & NA & NA & 2.7 & $1 \%$ & 2.1 & $1 \%$ \\
\hline Bathtub & 4.4 & $0.7 \%$ & NA & NA & 3.2 & $2 \%$ & 5.5 & $3 \%$ \\
\hline Toilet & 70 & $10.8 \%$ & 33.0 & $10 \%$ & 30.4 & $13 \%$ & 31.3 & $19 \%$ \\
\hline Irrigation & 381.6 & $58.7 \%$ & $180^{\dagger}$ & $54 \%$ & $57.4^{\dagger}$ & $25 \%$ & 13.9 & $8 \%$ \\
\hline Leak & 36.0 & $5.5 \%$ & 5.0 & $1 \%$ & 15.9 & $6 \%$ & 7.0 & $4 \%$ \\
\hline Other & 12.5 & $1.9 \%$ & NA & NA & 0.0 & $0 \%$ & 0.8 & $0 \%$ \\
\hline $\begin{array}{l}\text { Total } \\
\text { Consumption }\end{array}$ & 650.3 & $100 \%$ & 335.0 & $100 \%$ & 226.2 & $100 \%$ & 168.1 & $100 \%$ \\
\hline
\end{tabular}

${ }^{\top}$ Note: Irrigation volume per person calculated from provided volumes per household and end use break downs. 
Table 4. Socioeconomic descriptive statistics for sampled regions

\begin{tabular}{|c|c|c|c|c|c|}
\hline Research area & $\begin{array}{l}\text { Socioeconomic } \\
\text { classification }\end{array}$ & $\begin{array}{l}\text { Total no. of } \\
\text { Households }\end{array}$ & $\begin{array}{c}\text { Average } \\
\text { property size } \\
\left(\mathrm{m}^{2}\right) \\
\end{array}$ & $\begin{array}{l}\text { Average } \\
\text { income }\end{array}$ & $\begin{array}{c}\text { Education } \\
\text { status }\end{array}$ \\
\hline Mudgeeraba & $\begin{array}{l}\text { Lower Middle to } \\
\text { Middle Class }\end{array}$ & 36 & 646.8 & AUD $\$ 1387^{\dagger}$ & $\begin{array}{c}\text { Mainly High } \\
\text { School and } \\
\text { Technical }\end{array}$ \\
\hline Cassia Park & $\begin{array}{c}\text { Lower Middle to } \\
\text { Middle Class }\end{array}$ & 42 & 671.7 & AUD\$1730 & $\begin{array}{c}\text { Mainly High } \\
\text { School and } \\
\text { Technical }\end{array}$ \\
\hline Crystal Creek & $\begin{array}{l}\text { Lower Middle to } \\
\text { Middle Class }\end{array}$ & 38 & 655.6 & AUD\$1606 & $\begin{array}{c}\text { Mainly } \\
\text { Technical and } \\
\text { Tertiary }\end{array}$ \\
\hline \multirow[t]{2}{*}{ Coomera Waters } & $\begin{array}{c}\text { Middle to Upper } \\
\text { Middle Class } \\
\end{array}$ & 35 & 806.4 & AUD\$1987 & Mainly Tertiary \\
\hline & & 151 & 695.1 & AUD\$1677 & \\
\hline
\end{tabular}


Table 5. Measurement items mean value and standard deviation.

\begin{tabular}{|c|c|c|c|}
\hline $\begin{array}{l}\text { Item } \\
\text { Code }\end{array}$ & Item Description & Mean & S.D. \\
\hline \multicolumn{4}{|c|}{ Factor 1: Concern for environment (CE) } \\
\hline CE1 & Protection of natural environment for future generations & 4.64 & 0.59 \\
\hline CE2 & Community responsibility for reducing water consumption & 4.45 & 0.67 \\
\hline CE3 & Concern for environmental problems & 4.19 & 0.73 \\
\hline CE4 & $\begin{array}{l}\text { Joint responsibility of government and community to ensure water } \\
\text { security }\end{array}$ & 4.30 & 0.69 \\
\hline CE5 & Acknowledge water as being a valuable resource & 4.52 & 0.64 \\
\hline CE6 & Acknowledge role in creating a sustainable water future & 4.24 & 0.78 \\
\hline CE7 & $\begin{array}{l}\text { Valuing recycling, composting and other environmentally sustainable } \\
\text { activities }\end{array}$ & 4.22 & 0.72 \\
\hline CE8 & Acknowledge humans role as caretaker for environment & 4.36 & 0.64 \\
\hline \multicolumn{4}{|c|}{ Factor 2: Water conservation awareness and practice (WC) } \\
\hline WC1 & Awareness of opportunities to save water in household & 4.41 & 0.59 \\
\hline WC2 & $\begin{array}{l}\text { Awareness of the water saving benefits of retrofitting to water } \\
\text { efficient fixtures and appliances }\end{array}$ & 4.24 & 0.73 \\
\hline WC3 & Water meter reading competency & 3.44 & 0.88 \\
\hline WC4 & Monitoring of water use & 3.08 & 0.92 \\
\hline WC5 & $\begin{array}{l}\text { Awareness of the relationship between behaviour and water } \\
\text { consumption }\end{array}$ & 4.06 & 0.70 \\
\hline WC6 & Water saving knowhow & 4.23 & 0.69 \\
\hline WC7 & Perception on efficiency of household water use practices & 3.84 & 0.85 \\
\hline WC8 & Seeking continuous savings in water consumption over longer term & 4.11 & 0.75 \\
\hline WC9 & Regular reads water meter & 3.62 & 0.76 \\
\hline
\end{tabular}

Note: Cronbach’s alpha (17 items) = 0.91 
Table 6. Measurement model analysis results.

\begin{tabular}{|c|c|c|c|c|c|}
\hline Items & Loading & $t$-value ${ }^{\dagger}$ & $R^{2}$ & $\begin{array}{l}\text { Composite } \\
\text { Reliability }\end{array}$ & $\begin{array}{l}\text { Average } \\
\text { Variance } \\
\text { Extracted }\end{array}$ \\
\hline Factor 1 (CE) & & & & 0.90 & 0.60 \\
\hline CE1 & 0.74 & f.p. & 0.55 & & \\
\hline CE2 & 0.81 & 9.38 & 0.65 & & \\
\hline CE3 & 0.78 & 9.04 & 0.61 & & \\
\hline CE4 & 0.63 & 7.14 & 0.39 & & \\
\hline CE5 & 0.63 & 7.16 & 0.40 & & \\
\hline CE6 & 0.76 & 8.71 & 0.57 & & \\
\hline CE7 & 0.73 & 8.39 & 0.53 & & \\
\hline CE8 & 0.74 & 8.53 & 0.55 & & \\
\hline Factor $2(\mathrm{WC})$ & & & & 0.84 & 0.55 \\
\hline WC1 & 0.82 & f.p. & 0.67 & & \\
\hline WC2 & 0.73 & 9.20 & 0.53 & & \\
\hline WC3 & Removed & & & & \\
\hline WC4 & Removed & & & & \\
\hline WC5 & Removed & & & & \\
\hline WC6 & 0.77 & 9.82 & 0.59 & & \\
\hline WC7 & 0.56 & 6.65 & 0.32 & & \\
\hline WC8 & 0.62 & 7.53 & 0.39 & & \\
\hline WC9 & 0.55 & 6.42 & 0.30 & & \\
\hline
\end{tabular}


Table 7. Clustered comparative analysis results.

\begin{tabular}{|c|c|c|c|c|c|c|c|}
\hline \multirow[t]{2}{*}{ End-use category } & \multicolumn{3}{|c|}{$\begin{array}{c}\text { Average daily per capita water } \\
\text { consumption }(\mathrm{L} / \mathrm{p} / \mathrm{d})\end{array}$} & \multicolumn{4}{|c|}{$\begin{array}{l}\text { Cluster comparison statistics } \\
\text { (MHC versus VHC) }\end{array}$} \\
\hline & $\begin{array}{l}\text { Overall } \\
(n=132)\end{array}$ & $\begin{array}{l}\text { MHC } \\
(n=78)\end{array}$ & $\begin{array}{l}\text { VHC } \\
(n=54)\end{array}$ & $\begin{array}{l}\text { Difference } \\
\text { (L/p/d) }\end{array}$ & $\begin{array}{l}\text { Difference } \\
(\%)^{\dagger}\end{array}$ & $p$-value & $\begin{array}{c}\text { Significant at } \\
0.05 \text { level }(\mathrm{Y} / \mathrm{N}) ?\end{array}$ \\
\hline \multicolumn{8}{|c|}{ High extent - behaviourally influenced end uses } \\
\hline Shower & 47.1 & 51.0 & 41.5 & 9.5 & $18.6 \%$ & 0.043 & $\mathrm{Y}$ \\
\hline Clothes Washer & 30.1 & 33.6 & 25.0 & 8.6 & $25.6 \%$ & 0.031 & $\mathrm{Y}$ \\
\hline Tap & 26.6 & 29.2 & 22.9 & 6.3 & $21.6 \%$ & 0.002 & $\mathrm{Y}$ \\
\hline Irrigation & 18.0 & 23.0 & 10.8 & 12.2 & $53.0 \%$ & 0.049 & $\mathrm{Y}$ \\
\hline \multicolumn{8}{|l|}{ Other end uses } \\
\hline Dishwasher & 2.2 & 2.1 & 2.3 & 0.2 & $-9.5 \%$ & 0.609 & $\mathrm{~N}$ \\
\hline Bathtub & 5.5 & 6.2 & 4.5 & 1.7 & $27.4 \%$ & 0.314 & $\mathrm{~N}$ \\
\hline Toilet & 20.9 & 21.7 & 19.9 & 1.8 & $8.3 \%$ & 0.333 & $\mathrm{~N}$ \\
\hline Leak & 1.8 & 2.2 & 1.4 & 0.8 & $36.4 \%$ & 0.105 & $\mathrm{~N}$ \\
\hline Total consumption & 152.2 & 169.0 & 128.3 & 40.7 & $24.1 \%$ & 0.001 & $\mathbf{Y}$ \\
\hline
\end{tabular}

${ }^{\dagger}$ Relative to average daily per capita consumption of the MHC group (positive percentage represents a reduction in consumption) 


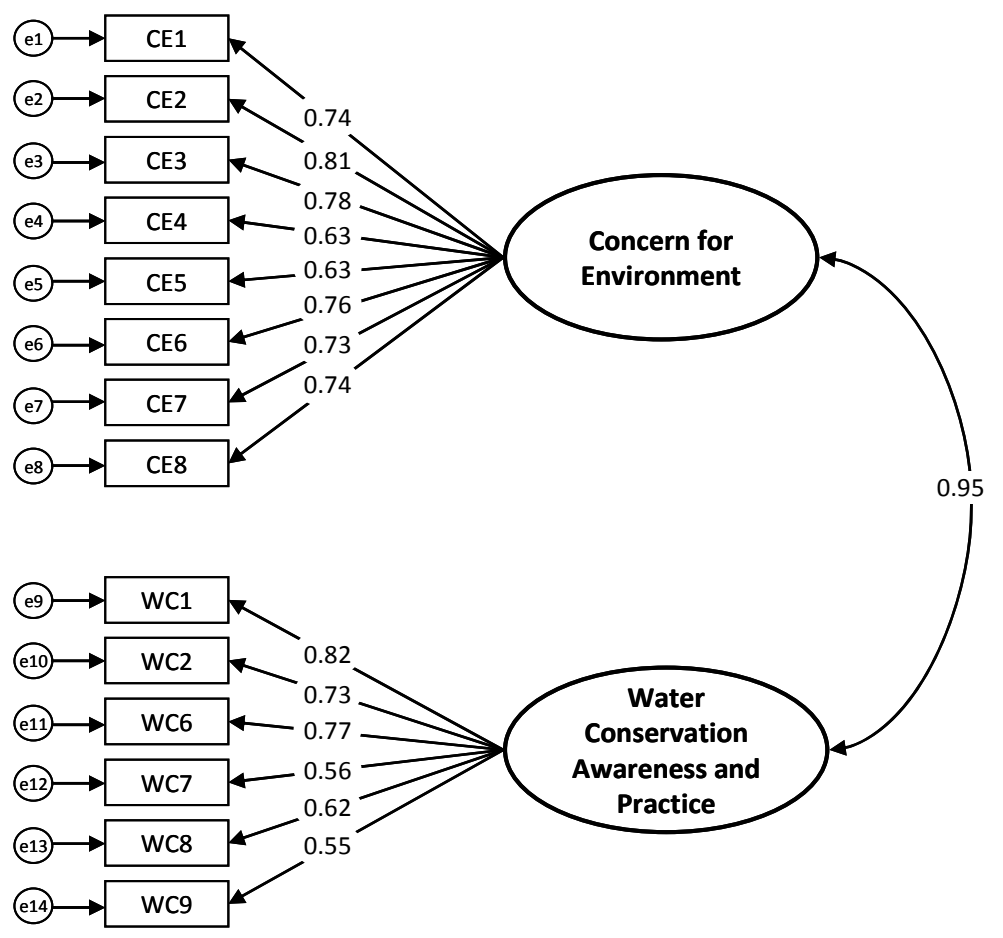

Figure 9. CFA Model.

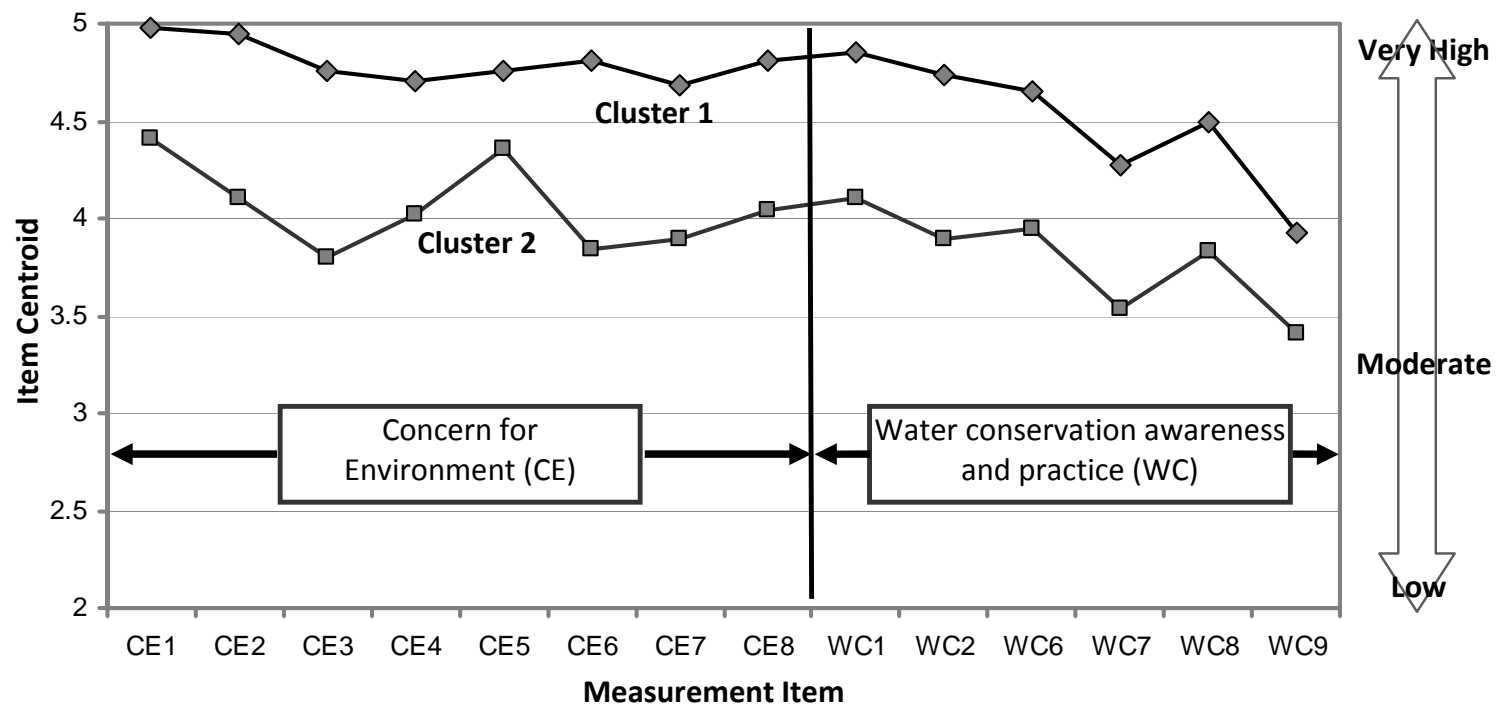

Figure 10. Profiles of clusters' final centroids. 




Figure 11. Average daily per capita consumption per end use: total sample (n=132).

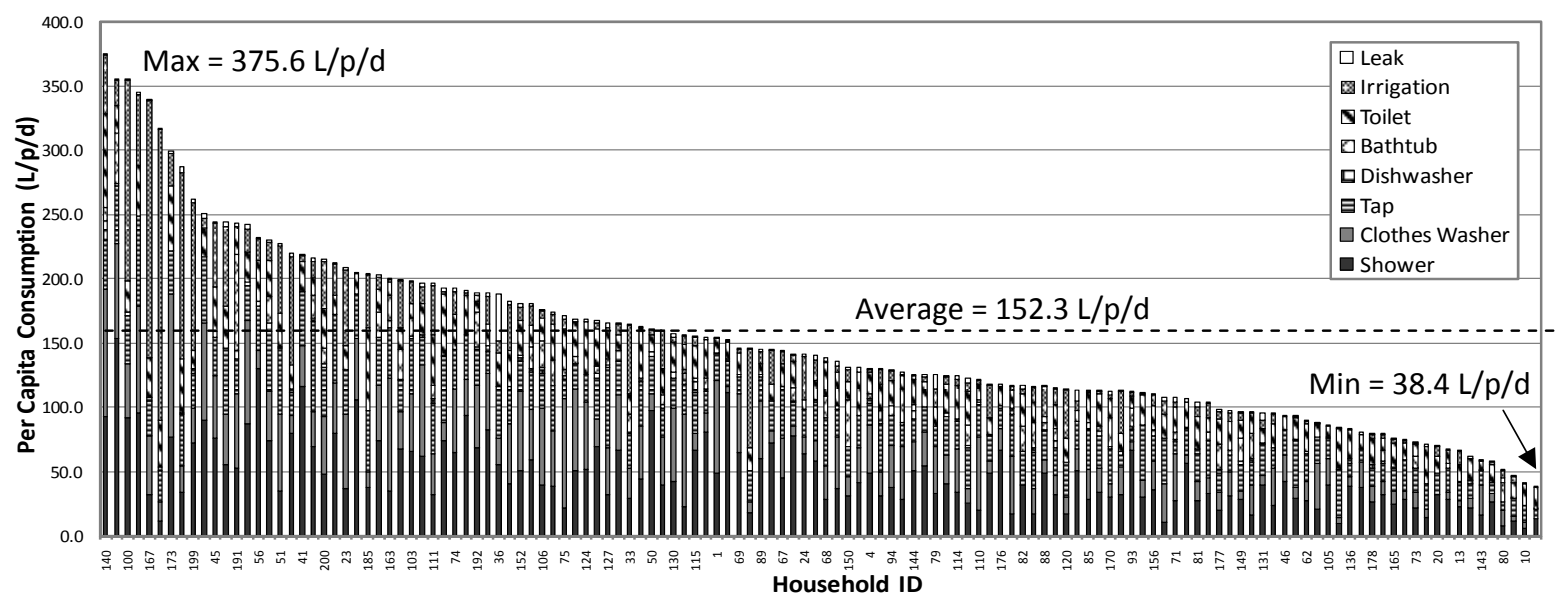

Figure 12. Household daily per capita consumption distribution with water end use breakdown: total sample $(\mathrm{n}=132)$. 


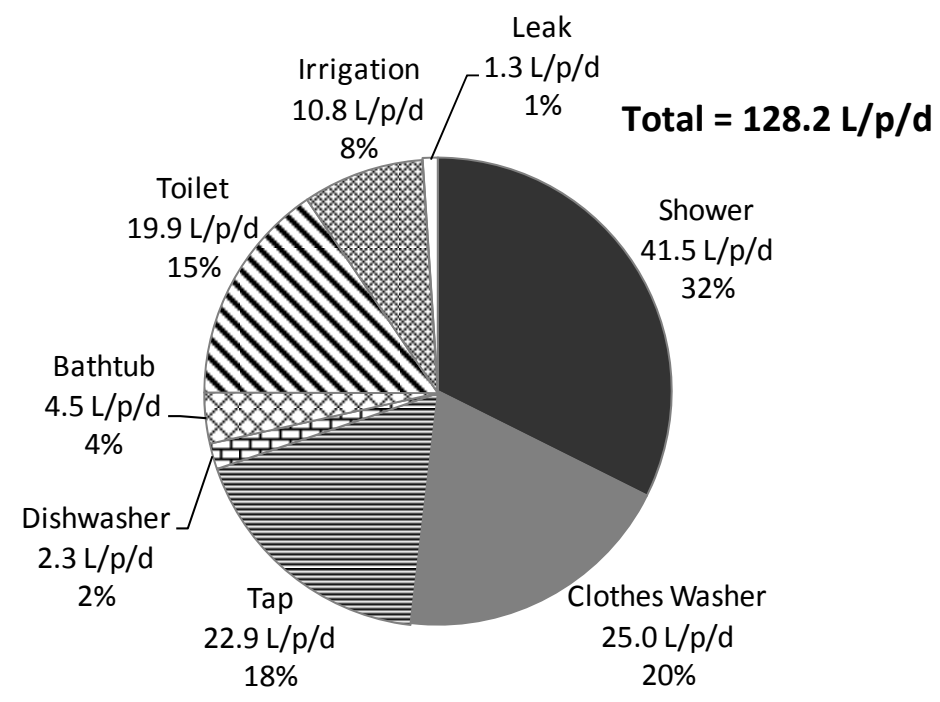

Figure 13. Average daily per capita consumption: VHC cluster ( $n=54)$.



Figure 14. Household daily per capita consumption distribution profile: VHC cluster $(n=54)$. 


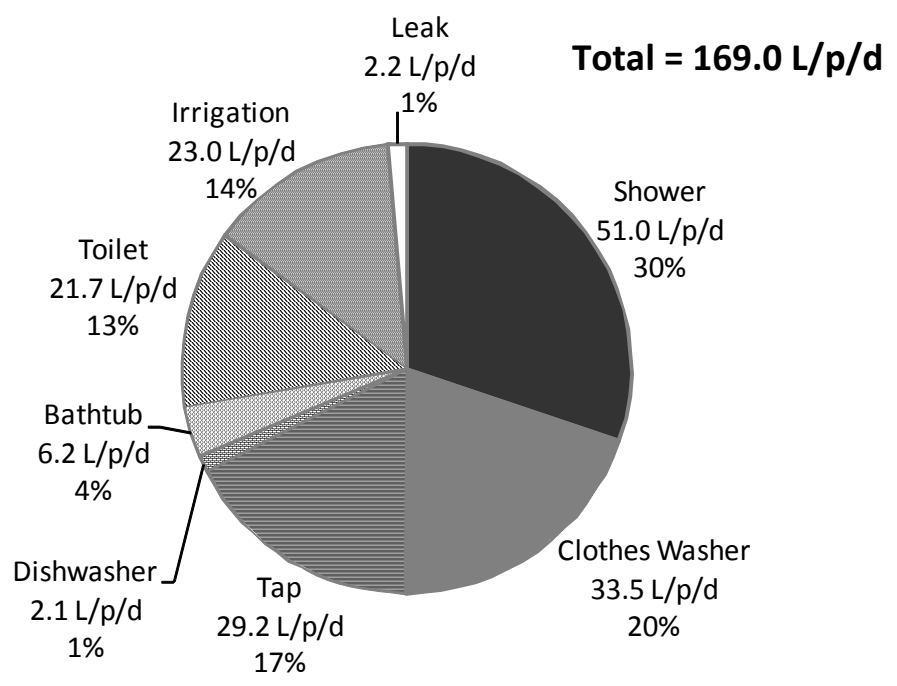

Figure 15. Average daily per capita consumption: MHC cluster ( $\mathrm{n}=78)$.

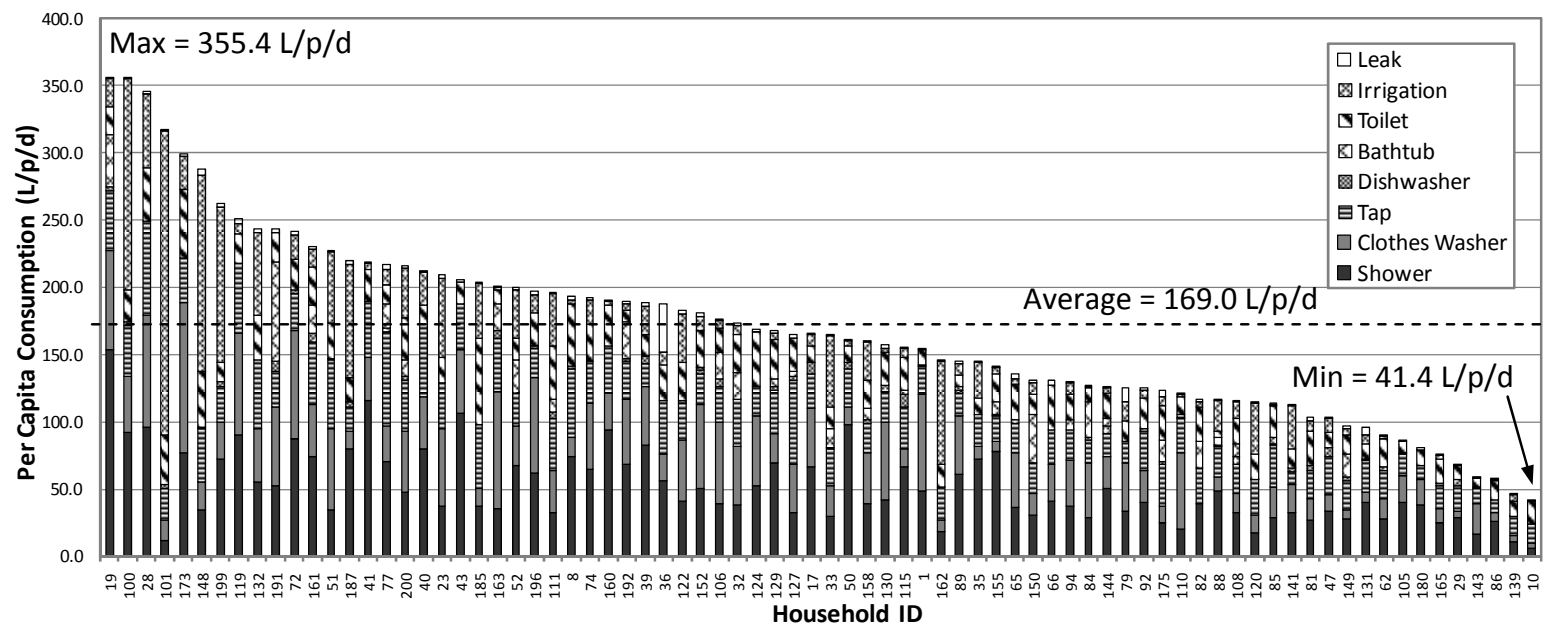

Figure 16. Household daily per capita consumption distribution profile: MHC cluster ( $n=78)$. 